\title{
SOSIALISASI PEMANFAATAN KACANG TANAH DALAM PEMBUATAN MENTEGA KACANG DI DESA CISITU DAN PENANGANAN LIMBAH CAIR INDUSTRI TAHU DI DESA SITUMEKAR KECAMATAN CISITU KABUPATEN SUMEDANG
}

\author{
Marta, H. dan Tensiska \\ Staf Pengajar Fakultas Teknologi Industri Pertanian Unpad \\ E-mail: elyne_marta@yahoo.com
}

\begin{abstract}
ABSTRAK
Program Pengabdian Masyarakat Dosen (PPMD) ini bertujuan untuk mengatasi permasalahan di kedua desa sasaran yaitu Desa Cisitu dan Desa Situmekar dengan cara (1) meningkatkan pengetahuan masyarakat desa Cisitu mengenai manfaat dan kandungan gizi kacang tanah serta meningkatkan keterampilan melalui pelatihan cara pengolahan kacang tanah menjadi mentega kacang, dan (2) meningkatkan kesadaran masyarakat Situmekar akan bahaya pencemaran lingkungan dan mensosialisasikan cara pengolahan limbah cair industri tahu menjadi pupuk organik cair dengan memanfaatkan hama bekicot sebagai unsur nitrogen. Kegiatan PPMD dilaksanakan di Desa Cisitu dan Desa Situmekar, Kecamatan Cisitu, Kabupaten Sumedang. Kegiatan PPMD ini dilakukan dengan cara: penyuluhan, demonstrasi dan praktek/pelatihan. Pelatihan ini dikatakan berhasil karena telah sesuai dengan indikator keberhasilan yang ditetapkan minimal $80 \%$ peserta memiliki nilai cukup dalam tes pengetahuan serta ketrampilan dalam pembuatan produk serta menyatakan bahwa pelatihan ini sangat berguna. Hasil penilaian kehadiran menunjukkan hasil $100 \%$ peserta datang untuk mengikuti pelatihan sampai selesai. Evaluasi terhadap pengetahuan dan keterampilan pada saat praktek memperlihatkan bahwa minimal $70 \%$ peserta telah memiliki kemampuan baik dalam persiapan, proses pengolahan dan hasil/produk. Sementara dari sikap atau respon terhadap kegiatan pelatihan ini $\mathbf{9 0 \%}$ menyatakan sangat bermanfaat dan $10 \%$ menyatakan bermanfaat.
\end{abstract}

Kata Kunci: kacang tanah, mentega kacang, limbah cair industri tahu, pupuk organik cair

\section{ABSTRACT}

Community Service Program ( PPMD) aims to overcome the problems in the two villages targeted were the Cisitu Village and Situmekar Village by (1) increasing knowledge about the Cisitu villagers and nutritional benefits of peanuts as well as improving skills through training in peanut processing into peanut butter, and (2) increase public awareness of the dangers of environmental pollution in Situmekar and disseminating industrial tofu wastewater treatment way out into liquid organic fertilizer with pest snails utilize as nitrogen source. Community Service Program activities carried out in the Cisitu village and Situmekar village, District Cisitu, Sumedang . PPMD activity is carried out by means of: lectures, demonstrations and practice/training. This training is successful because it had been in accordance with the indicators of success are set at least $80 \%$ of participants have sufficient value to test knowledge and skills in the manufacture of products as well as stating that the training was very useful. The results indicate the presence of assessment results of $100 \%$ of the participants came for training to complete.
Evaluation of knowledge and skills during practice showed that at least $70 \%$ of participants had had a good ability in the preparation, processing and results / products. While the attitude or response to this training at least $90 \%$ said very useful.

Key words: peanut, peanut butter, industrial tofu wastewater, liquid organic fertilizer

\section{PENDAHULUAN}

Sektor pertanian merupakan salah satu sektor yang diharapkan dapat memberikan sumbangan yang berarti dalam peningkatan pendapatan nasional terutama dalam penyediaan lapangan kerja dan penyediaan bahan baku. Salah satu sektor pertanian yang memegang peranan penting dalam penyerapan tenaga kerja yaitu sektor agroindustri di bidang pengembangan produksi pangan Menurut Widodo (2003), pengembangan produksi pangan bertujuan untuk menyajikan bahan menjadi lebih siap dikonsumsi dan meningkatkan kualitas sehingga dapat meningkatkan harga jualnya.

Lahan di Desa Cisitu Kecamatan Cisitu, Kabupaten Sumedang didominasi oleh lahan pertanian dan permukiman, sebagian lainnya digunakan untuk lahan usaha dan kebun rakyat. Salah satu jenis bahan bahan pangan yang mempunyai prospek untuk dikembangkan di Desa Cisitu adalah kacang tanah. Kacang tanah merupakan salah satu komoditas sektor pertanian tanaman bahan pangan yang sering dijadikan bahan baku industri makanan olahan. Menurut Purnomo dan Purnamawati (2007), biji kacang tanah mengandung kadar lemak dan protein tinggi. Kandungan proteinnya sekitar 30\%, terdiri dari asam-asam amino esensial seperti arginin, fenilalanin, isoleusin, leusin, lisin, metionin, triptofan, dan valin sedangkan kandungan lemaknya sekitar 16-50\% yang terdiri dari asam lemak tidak jenuh seperti asam oleat dan linoleat.

Produksi kacang tanah di Desa Cisitu cukup tinggi dengan luas area lahan sekitar 4071 ha. Namun, pemanfaatannya masih terbatas hanya dijual dalam bentuk kacang tanah mentah dan biji kacang tanah kering. Untuk memperpanjang umur simpan serta dalam rangka diversifikasi pangan, kacang tanah dapat diolah menjadi berbagai aneka produk olahan pangan misalnya mentega kacang. Dengan diolahya kacang tanah menjadi mentega kacang dapat meningkatkan nilai ekonomis dari kacang tanah. Mentega kacang merupakan olahan kacang tanah yang dapat diaplikasikan sebagai bahan pelengkap berbagai olahan roti dan penganan kecil lainnya.

Desa Situmekar juga memiliki potensi di bidang pertanian. Hal ini dapat terlihat dari luasnya wilayah persawahan yang terdapat di Desa Situmekar. Luas areal persawahan di Desa Situmekar adalah 117 Ha. Selain itu, di Desa Situmekar juga terdapat 8 industri 
pengolahan tahu. Industri tersebut memiliki masalah dalam hal pembuangan limbah cair, dimana limbah cair ini dibuang ke sungai, danau, dan perairan lainnya sehingga dapat menyebabkan polusi dan tercemarnya sistem irigasi pertanian yang terdapat di Desa Situmekar. Pencemaran lingkungan yang diakibatkan oleh limbah cair industri tahu ini diprotes oleh masyarakat, sehingga diperlukan solusi untuk mengatasi masalah ini. Salah satu alternatif solusi untuk mengatasi masalah tersebut adalah dengan mengolah limbah cair industri tahu menjadi pupuk organik cair.

Permasalahan lain yang terekam di Desa Situmekar adalah hama bekicot. Biasanya bekicot menjadi masalah bagi petani saat memasuki taman dan kerap kali bekicot merusak tanaman petani. Terlihat menempel di dinding, memakan daun atau tunas yang baru tumbuh juga kerap membuat jijik. Bekicot menyukai tempat-tempat lembab, itu sebabnya pada musim hujan, bekicot bermunculan. Selain itu, pada musim hujan pula bekicot berkembang biak dengan pesat. Sebenarnya bekicot dapat dimanfaatkan sebagai sumber unsur Nitrogen $(\mathrm{N})$ dalam pembuatan pupuk organik cair, sehingga dalam program pemanfaatan limbah cair industri tahu menjadi pupuk organik cair juga memanfaatkan bekicot sebagai sumber unsur N.

Dengan adanya kondisi, potensi, dan juga kendala yang dihadapi oleh masyarakat petani kacang tanah di Desa Cisitu, Kecamatan Cisitu perlu adanya pembinaan dan pelatihan untuk dapat mengoptimalkan pemanfaatan dan diversifikasi olahan kacang tanah sebagai upaya pengembangan ketahanan pangan melalui pemberdayaan masyarakat. Sementara di Desa Situmekar perlu disosialisasikan cara pengolahan limbah cair dari industri tahu menjadi pupuk organik cair dengan penambahan bekicot sebagai sumber unsur Nitrogen, sehingga dapat mengatasi masalah lingkungan di Desa Situmekar.

Tujuan program PPMD ini adalah:

1. mensosialisasikan dan melatih masyarakat Desa Cisitu untuk memanfaatkan hasil pertanian lokal Desa tersebut (kacang tanah) menjadi produk olahan pangan (mentega kacang)

2. mensosialisasikan dan melatih masyarakat Desa Situmekar mengenai cara memanfaatkan limbah cair industri tahu menjadi pupuk organik cair dengan penambahan bekicot sebagai sumber unsur Nitrogen.

Manfaatnya PPMD bagi masyarakat adalah mendorong masyarakat untuk memanfaatkan potensi daerah masing-masing menjadi produk yang memiliki nilai ekonomis yang lebih tinggi, dalam hal ini pengolahan kacang tanah menjadi mentega kacang di Desa Cisitu dan pemanfaatan limbah cair industri tahu menjadi pupuk organik cair di Desa Situmekar.

\section{MATERI DAN METODE}

\section{Kerangka Pemecahan Masalah}

Pemecahan masalah didekati dengan metode penyuluhan dan pelatihan. Masing-masing Desa memiliki permasalahan yang berbeda-beda. Di Desa Cisitu, penyuluhan dilakukan untuk menjelaskan mengenai kandungan gizi kacang tanah dan manfaatnya bagi kesehatan. Sementara kegiatan pelatihan dilakukan untuk mensosialisasikan cara pengolahan kacang tanah menjadi mentega kacang yang bernilai ekonomis lebih tinggi. Sementara di Desa Situmekar, dilakukan penyuluhan mengenai pentingnya menjaga lingkungan dan bahaya pencemaran lingkungan oleh limbah cair industri tahu. Kegiatan pelatihan dilakukan untuk mensosialisasikan cara pemanfaatan limbah cair industri pengolahan tahu menjadi pupuk organik cair.

Kegiatan tersebut didahului dengan mencari informasi tentang kondisi awal keadaan masyarakat yang berhubungan dengan keberadaan kacang tanah di Desa Cisitu dan produksi limbah cair industri tahu di Desa Situmekar sebagai objek utama pada Pengabdian kepada Masyarakat ini. Setelah pelatihan dilaksanakan, peserta diberi lembar pertanyaan (kuesioner) untuk diisi dan diminta responnya mengenai kegiatan ini. Hasil pelatihan dan data dari kuesioner yang dikumpulkan dianalisis untuk menentukan hasil yang dapat dicapai dari kegiatan ini serta kemungkinan membuat rencana keberlanjutan program ini.

\section{Realisasi Penyelesaian Masalah}

Program PPMD ini dirancang dalam beberapa kegiatan untuk menyelesaikan permasalahan di Desa Cisitu dan Desa Situmekar. Kegiatan yang dilaksanakan sebagian besar sesuai dengan perencanaan awal. Adapun rincian kegiatan tersebut antara lain:

Kegiatan Sosialisasi dan Pelatihan Pemanfaatan Limbah Cair Industri Pengolahan Tahu menjadi Pupuk Organik Cair dilakukan di Balai Desa Situmekar pada tanggal 27 Januari 2014. Peserta terdiri dari perwakilan pengusaha industri tahu, anggota kelompok tani dan pamong desa. Foto-foto kegiatan penyuluhan dan pelatihan pembuatan pupuk organik cair.

Kegiatan Sosialisasi dan Pelatihan Pemanfaatan Kacang Tanah sebagai Bahan Baku Pembuatan Mentega Kacang dilakukan di Balai Desa Cisitu pada tanggal 13 Februari 2014.Kegiatan diawali dengan penyuluhan mengenai kandungan gizi, manfaat serta potensi kacang tanah sebagai bahan baku pembuatan mentega kacang. Foto-foto kegiatan penyuluhan dan pelatihan pembuatan mentega kacang .

\section{Khalayak Sasaran}

Kegiatan pelatihan telah dilakukan di Desa Cisitu dan Desa Situmekar Kecamatan Cisitu Kabupaten Sumedang, Jawa Barat. KKNM-PPMD Integratif ini mengambil sasaran kelompok PKK dan masyarakat tani kacang tanah di Desa Cisitu serta pelaku usaha industri pengolahan tahu di Desa Situmekar Kecamatan Cisitu sebanyak 30 orang. Waktu PPMD selama 4 bulan dengan waktu pelatihan sebanyak 3 kali tatap muka. Peserta merupakan perwakilan dusun yang memiliki kemampuan untuk mensosialisasikannya kembali kepada warga masyarakat di wilayahnya. Pemilihan masyarakat tani dan anggota kelompok PKK dilakukan oleh pihak desa dan kemudian diputuskan oleh pihak dusun dan begitu juga dengan pelaku usaha pengolahan tahu. Kegiatan ini juga melibatkan mahasiswa dari Universitas Padjadjaran yang sedang melakukan KKNM selama 1 bulan di lokasi tersebut. 


\section{Metode yang Digunakan}

Berbagai metode yang akan digunakan untuk menyelesaikan permasalahan tersebut adalah sebagai berikut:

a. Melakukan penyuluhan untuk meningkatkan pengetahuan para peserta dengan materi : (1) Pengetahuan mengenai kacang tanah meliputi: kandungan gizi dan keunggulannya, (2) Pengetahuan mengenai cara pengolahan kacang tanah menjadi mentega kacang dan cara produksi pangan yang baik, (3) Pengemasan dan Pelabelan, (4) Bahaya pencemaran lingkungan, dan (4) Penanganan dan pemanfaatan limbah cair untuk diolah menjadi pupuk organik cair.

Metode pembelajaran dalam pelatihan teori ini menggunakan metode ceramah dan demonstrasi. Metode ceramah dipilih untuk menyampaikan teori dan konsep-konsep substansi yang sangat prinsip dan penting, yang harus dikuasai oleh peserta pelatihan. Substansi tersebut berupa materi pokok yaitu berkaitan dengan pengetahuan tentang bahan, cara pengolahannya dan pengemasan serta pelabelan produk tersebut serta penanganan dan pemanfaatan limbah.. Demonstrasi sangat penting keberadaanya dalam kegiatan pelatihan ini, karena dalam pelatihan suatu proses kerja akan lebih mudah diikuti oleh peserta pelatihan manakala keterampilan yang akan ditransformasikan bisa dieksplisitkan secara konkrit melalui demonstrasi. Adapun materi yang menggunakan pendekatan metode demonstrasi pada pelatihan teori adalah cara pengolahan dan pengemasan mentega kacang serta pengolahan limbah cair.

b. Penyelenggaraan pelatihan praktek pengolahan kacang tanah menjadi mentega kacang dan pemanfaatan limbah cair industri tahu menjadi pupuk organik cair. Pada pengolahan mentega kacang, praktek dilakukan mulai dari cara mempersiapkan kacang tanah sebagai bahan makanan dan pengolahannya menjadi mentega kacang. Pada penanganan dan pemanfaatan limbah cair industri tahu, praktek dilakukan mulai dari penangan limbah cair dan pembuatan pupuk organik cair dari limbah industri tahu. Metode pembelajaran yang digunakan untuk kelancaran pelatihan adalah demonstrasi dan metode latihan. Metode demonstrasi diberikan agar peserta melihat prosedur praktek dengan baik dan kemudian dapat mengikuti melalui latihan. Metode latihan atau praktek ini diberikan kepada para peserta pelatihan dengan harapan peserta pelatihan akan mempunyai pengalaman langsung dengan melakukan sendiri atau mempraktekan materi pelatihan tentang prosedur atau langkah kerja dalam pengolahan mentega kacang dan pembuatan pupuk cair dari limbah industri tahu.

\section{HASIL DAN PEMBAHASAN}

\section{Hasil yang Dicapai}

1. Pemanfaatan Limbah Cair Industri Pengolahan Tahu menjadi Pupuk Organik Cair di Desa Situmekar
Kegiatan Pemanfaatan Limbah Cair Industri Pengolahan Tahu menjadi Pupuk Organik di Desa Situmekar berhasil dilaksanakan dengan baik. Kegiatan ini dimulai dari pemaparan teori mengenai bahaya pencemaran lingkungan dan potensi limbah cair industri pengolahan tahu untuk dimanfaatkan menjadi pupuk organik cair, penjelasan singkat mengenai cara pembuatan pupuk organik cair, serta praktik pembuatan pupuk organik cair.

Penyampaian materi untuk meningkatkan pengetahuan dilakukan dengan metode ceramah dan tanya jawab. Materi yang diberikan adalah:

1) bahaya pencemaran lingkungan

2) komposisi kimia limbah cair industri pengolahan tahu serta potensinya untuk diolah menjadi pupuk organik cair

3) potensi hama bekicot untuk dijadikan sumber unsur Nitrogen dalam pembuatan pupuk organik cair

Pemberian materi diawali dengan penjelasan dan demonstrasi cara pembuatan pupuk organik cair, kemudian kepada peserta dibagi dalam 4 kelompok dan dipersilahkan untuk melakukan sendiri cara membuat pupuk organik cair. Pada tahap awal dilakukan persiapan bahan antara lain limbah cair industri tahu, bakteri EM4, keong/bekicot, gula pasir/molase. Setelah itu dilakukan pencampuran bahan dan diaduk hingga homogen. Tahap terakhir campuran tersebut difermentasi selamma 7-10 hari, setelah itu pupuk organilk siap digunakan. Secara rinci proses pembuatan pupuk organik cair dapat dilihat pada Lampiran. Pelatihan praktek dilakukan selama 60 menit.

Hasil produk yang sudah jadi (setelah 1 minggu) kemudian dievaluasi bersama-sama sehingga peserta menjadi tahu kekurangan dan kelebihan produk yang sudah dibuat. Fermentasi selesai ditandai dengan timbulnya panas pada wadah.

Evaluasipelatihan teori dilakukanuntukmengetahui pemahaman peserta akan potensi pemanfaatan limbah cair industri tahu untuk dibuat menjadi pupuk organik cair. Evaluasi dilakukan dengan memberikan beberapa pertanyaan kepada peserta pelatihan sebelum dan setelah materi teori diberikan. Dari segi teori kriteria keberhasilannya adalah setelah pelatihan, peserta pelatihan mampu menjawab dengan benar pertanyaan yang diberikan minimal $80 \%$. Hasil evaluasi terhadap pengetahuan peserta pelatihan pembuatan pupuk organik cair dapat dilihat pada Tabel 1.

Tabel 1. Hasil Evaluasi terhadap Pengetahuan Peserta Pelatihan Pembuatan Pupuk Organik Cair

\begin{tabular}{lcc}
\hline \multirow{2}{*}{ Kriteria Penilaian } & \multicolumn{2}{c}{ Jumlah Peserta (\%) } \\
\cline { 2 - 3 } & $\begin{array}{c}\text { Sebelum } \\
\text { Pelatihan }\end{array}$ & Setelah Pelatihan \\
\hline Rendah $(<50 \%)$ & 89 & 0 \\
Sedang $(50-80 \%)$ & 11 & 10 \\
Tinggi $(>80 \%)$ & 0 & 90 \\
Total & 100 & 100 \\
\hline
\end{tabular}


Evaluasi pelatihan praktek dilakukan untuk mengetahui kemampuan peserta dalam mengolah limbah cair tahu menjadi pupuk organik cair. Evaluasi dilakukan pada saat proses atau praktek membuat pupuk organik cair. Peserta diamati dengan lembar pengamatan yang terdiri dari 3 kriteria, yaitu: persiapan, proses pengolahan dan hasil. Khusus untuk penilaian hasil dilakukan setelah fermentasi (setelah 7 hari). Hasil evaluasi terhadap keterampilan peserta pelatihan pembuatan pupuk organik cair dapat dilihat pada Tabel 2.

Tabel 2. Hasil Evaluasi Terhadap Keterampilan Peserta Pelatihan Pembuatan Pupuk Organik Cair

\begin{tabular}{lcc}
\hline \multirow{2}{*}{ Kriteria } & \multicolumn{2}{c}{ Jumlah Peserta (\%) } \\
\cline { 2 - 3 } & $\begin{array}{c}\text { Persiapan } \\
\text { Bahan }\end{array}$ & Proses Pengolahan \\
\hline Rendah $(<60 \%)$ & - & - \\
Sedang $\quad(60$ & 28 & 21 \\
$80 \%)$ & & \\
Tinggi $(>80 \%)$ & 72 & 79 \\
Total & 100 & 100 \\
\hline
\end{tabular}

Evaluasi sikap peserta terhadap kegiatan pelatihan pemanfaatan dan diversifikasi olahan kacang tanah untuk meningkatkan umur simpan dan harga jual kacang tanah dapat dilihat pada Tabel 3.

Tabel 3. Hasil Evaluasi Sikap terhadap Kegiatan Pelatihan Pembuatan Pupuk Organik Cair

\begin{tabular}{lc}
\hline \multicolumn{1}{c}{ Kriteria } & Jumlah Peserta (\%) \\
\hline Kurang bermanfaat & - \\
Bermanfaat & 8 \\
Sangat bermanfaat & 92 \\
Total & 100 \\
\hline
\end{tabular}

Hasil pelaksanaan kegiatan PPMD-KKNM Integratif ini menunjukkan bahwa peserta pelatihan memiliki pengetahuan, sikap dan keterampilan yang baik dalam pengolahan limbah cair industri tahu menjadi pupuk organik cair. Hasil ini ditunjukkan dari tes pengetahuan dan lembar pengamatan praktik. Hasil tersebut juga menunjukkan bahwa pelatihan yang diberikan telah memberikan manfaat dalam meningkatkan pemahaman untuk memanfaatkan limbah cair indutri tahu sebagai bahan baku pembuatan pupuk organik cair. Berdasarkan hasil evaluasi respon atau sikap diketahui bahwa menurut peserta adanya pelatihan ini sangat berguna dan bermanfaat.

Berdasarkan hasil pada Tabel 1, 2 dan 3, pelatihan ini dikatakan berhasil karena telah sesuai dengan indikator keberhasilan yang ditetapkan, yaitu pelatihan dinyatakan berhasil apabila minimal $80 \%$ peserta mengikuti pelatihan sampai selesai dan dibuktikan dari presentasi kehadiran, dan lebih dari $80 \%$ peserta memiliki nilai tinggi (> 80\%) dalam tes pengetahuan serta ketrampilan sehingga dinyatakan kreatif dan dapat mengolah limbah cair industri tahu menjadi pupuk organik cair dengan memanfaatkan hama bekicot sebagai sumber unsur nitrogen. Hasil penilaian kehadiran menunjukkan hasil $100 \%$ peserta datang untuk mengikuti pelatihan sampai selesai. Sedangkan evaluasi terhadap pengetahuan dan ketrampilan pada saat praktek sudah terlihat bahwa lebih dari $70 \%$ telah memiliki pengetahuan dan kemampuan baik dalam persiapan, proses dan karakteristik produk akhir. Sementara dari sikap atau respon terhadap kegiatan pelatihan ini $92 \%$ menyatakan sangat bermanfaat dan $8 \%$ menyatakan bermanfaat.

Output yang diharapkan dalam kegiatan pelatihan pemanfaatan limbah cair industri tahu adalah peserta memiliki kesadaran akan bahaya pencemaran lingkungan, memiliki pengetahuan dan keterampilan dalam memanfaatkan limbah cair industri tahu dan hama bekicot menjadi pupuk organik cair. Selain itu, peserta juga diharapkan memiliki motivasi untuk membuka usaha di bidang pengolahan limbah cair industri tahu. Dampak dari kegiatan ini diharapkan agar kegiatan pemanfaatan limbah cair industri tahu menghasilkan pupuk organik cair yang mempunyai nilai ekonomis dan jangka panjangnya dapat membantu meningkatkan pendapatan keluarga melalui rintisan usaha produksi pupuk organik cair.

2. Kegiatan Sosialisasi dan Pelatihan Pemanfaatan Kacang Tanah sebagai Bahan Baku Pembuatan Mentega Kacang di Desa Cisitu.

Kegiatan sosialisasi pemanfaatan kacang tanah sebagai bahan baku pembuatan mentega kacang di Desa Cisitu berhasil dilaksanakan dengan baik. Kegiatan ini dimulai dari pemaparan teori mengenai manfaat dan kandungan gizi kacang tanah serta potensinya untuk diolah menjadi berbagai macam produk olahan pangan, salah satunya adalah mentega kacang, penjelasan singkat mengenai cara pembuatan mentega kacang, praktek pembuatan mentega kacang serta display produk sebagai bentuk motivasi kepada peserta. Materi pelatihan disusun sesuai dengan kebutuhan dan kemampuan peserta yang memiliki pengetahuan terbatas tentang cara pengolahan mentega kacang sehingga menghasilkan menghasilkan produk olahan yang mempunyai karakteristik baik dan layak jual.

Penyampaian materi untuk meningkatkan pengetahuan dilakukan dengan metode ceramah dan tanya jawab. Materi yang diberikan adalah:

a) kandungan gizi, manfaat serta potensi kacang tanah sebagai bahan baku produk olahan pangan

b) pemanfaatan dan diversifikasi produk olahan kacang tanah

c) pengemasan dan pelabelan

d) cara pemasaran produk yang baik

Materi praktek diberikan pada tahap pelatihan praktek. Tahap ini dilakukan melalui penyelenggaraan pelatihan ketrampilan mengolah kacang tanah yang menitik beratkan pada kemampuan mengolah kacang tanah menjadi mentega kacang.

Pemberian materi diawali dengan penjelasan dan demonstrasi cara pembuatan produk, kemudian kepada peserta dibagi dalam 4 kelompok dan dipersilahkan untuk melakukan sendiri cara membuat produk mulai dari persiapan sampai produk jadi dan siap dikonsumsi. Pelatihan praktek dilakukan selama 180 menit. Hasil produk yang sudah jadi kemudian dievaluasi bersama-sama sehingga peserta menjadi 
tahu kekurangan dan kelebihan produk yang sudah dibuat. Dengan demikian mereka juga memperoleh pengetahuan tentang karakteristik masing-masing produk.

Evaluasi pelatihan teori dilakukan untuk mengetahui pemahaman peserta akan manfaat kacang tanah baik gizi maupun potensinya sebagai bahan baku pembuatan produk olahan pangan. Evaluasi dilakukan dengan memberikan beberapa pertanyaan kepada peserta pelatihan setelah materi teori diberikan. Dari segi teori kriteria keberhasilannya adalah peserta pelatihan mampu menjawab dengan benar pertanyaan yang diberikan minimal $80 \%$. Hasil evaluasi pengetahuan peserta pelatihan pembuatan mentega kacang dapat dilihat pada Tabel 4.

Tabel 4. Hasil Evaluasi terhadap Pengetahuan Peserta Pelatihan Pembuatan Mentega Kacang

\begin{tabular}{lcc}
\hline \multirow{2}{*}{ Kriteria Penilaian } & \multicolumn{2}{c}{ Jumlah Peserta (\%) } \\
\cline { 2 - 3 } & $\begin{array}{c}\text { Sebelum } \\
\text { Pelatihan }\end{array}$ & Setelah Pelatihan \\
\hline Rendah $(<50 \%)$ & 89 & 0 \\
Sedang $(50-80 \%)$ & 11 & 10 \\
Tinggi $(>80 \%)$ & 0 & 90 \\
Total & 100 & 100 \\
\hline
\end{tabular}

Evaluasi pelatihan praktek dilakukan untuk mengetahui kemampuan peserta dalam mengolah kacang tanah menjadi mentega kacang. Evaluasi dilakukan pada saat proses atau praktek membuat mentega kacang. Peserta diamati dengan lembar pengamatan yang terdiri dari 3 kriteria, yaitu: persiapan, proses pengolahan dan produk akhir. Hasil evaluasi terhadap keterampilan peserta pelatihan pembuatan mentega kacang dapat dilihat pada Tabel 5 dan evaluasi sikap peserta terhadap kegiatan pelatihan pengolahan kacang tanah menjadi mentega kacang dapat dilihat pada Tabel 6 .

Tabel 5. Hasil Evaluasi terhadap Keterampilan Peserta Pelatihan Pembuatan Mentega Kacang

\begin{tabular}{lccc}
\hline \multirow{2}{*}{ Kriteria } & \multicolumn{3}{c}{ Jumlah Peserta (\%) } \\
\cline { 2 - 4 } & $\begin{array}{c}\text { Persiapan } \\
\text { Bahan }\end{array}$ & $\begin{array}{c}\text { Proses } \\
\text { Pengolahan }\end{array}$ & $\begin{array}{c}\text { Display } \\
\text { Produk }\end{array}$ \\
\hline $\begin{array}{l}\text { Rendah }(< \\
60 \%)\end{array}$ & - & - & - \\
$\begin{array}{l}\text { Sedang }(60- \\
80 \%)\end{array}$ & 29 & 24 & 30 \\
$\begin{array}{l}\text { Tinggi }(> \\
80 \%)\end{array}$ & 71 & 76 & 70 \\
Total & 100 & 100 & 100 \\
\hline
\end{tabular}

Tabel 6. Hasil Evaluasi Sikap terhadap Kegiatan Pelatihan Pembuatan Mentega Kacang

\begin{tabular}{lc}
\hline \multicolumn{1}{c}{ Kriteria } & $\begin{array}{c}\text { Jumlah } \\
\text { Peserta (\%) }\end{array}$ \\
\hline Kurang bermanfaat & - \\
Bermanfaat & 10 \\
Sangat bermanfaat & 90 \\
Total & 100 \\
\hline
\end{tabular}

Hasil pelaksanaan kegiatan PPMD-KKNM Integratif ini menunjukkan bahwa peserta pelatihan memiliki pengetahuan, sikap dan keterampilan yang baik dalam memahami kandungan gizi dan pemanfaatan kacang tanah sebagai bahan makanan bergizi tinggi serta berpotensi untuk dikembangkan dalam pembuatan berbagai produk olahan pangan.

Hasil ini ditunjukkan dari tes pengetahuan dan lembar pengamatan praktek. Hasil tersebut juga menunjukkan bahwa pelatihan yang diberikan telah memberikan manfaat dalam meningkatkan pemahaman untuk memanfaatkan kacang tanah sebagai bahan baku pembuatan mentega kacang dengan karakteristik organoleptik yang baik. Berdasarkan hasil evaluasi respon atau sikap diketahui bahwa menurut peserta adanya pelatihan ini sangat berguna dan bermanfaat.

Berdasarkan hasil pada Tabel 4, 5 dan 6, pelatihan ini dikatakan berhasil karena telah sesuai dengan Indikator keberhasilan yang ditetapkan, yaitu pelatihan dinyatakan berhasil apabila minimal $80 \%$ peserta mengikuti pelatihan sampai selesai dan dibuktikan dari presentasi kehadiran, dan lebih dari $80 \%$ peserta memiliki nilai tinggi ( $>80 \%$ ) dalam tes pengetahuan serta keterampilan sehingga dinyatakan kreatif dan dapat mengolah kacang tanah menjadi mentega kacang. Hasil penilaian kehadiran menunjukkan hasil $100 \%$ peserta datang untuk mengikuti pelatihan sampai selesai. Sedangkan evaluasi terhadap pengetahuan dan ketrampilan pada saat praktek sudah terlihat bahwa lebih dari 70\% telah memiliki pengetahuan dan kemampuan baik dalam persiapan, proses dan penyajian. Sementara dari sikap atau respon terhadap kegiatan pelatihan ini $90 \%$ menyatakan sangat bermanfaat dan $10 \%$ menyatakan bermanfaat.

Output yang diharapkan dalam kegiatan pelatihan pemanfaatan kacang tanah adalah peserta memiliki pengetahuan dan keterampilan dalam memanfaatkan kacang tanah menjadi mentega kacang yang layak untuk dipasarkan. Selain itu, peserta juga diharapkan memiliki motivasi untuk membuka usaha di bidang pengolahan kacang tanah, sedangkan dampak sebagai kelanjutannya mengharapkan agar kegiatan pemanfaatan kacang tanah sebagai bahan makanan yang mempunyai nilai jual dan jangka panjangnya dapat membantu meningkatkan pendapatan keluarga melalui rintisan usaha olahan kacang tanah, dalam hal ini mentega kacang.

\section{Keberlanjutan Program}

Kegiatan ini dinilai efektif oleh peserta (berdasarkan hasil evaluasi), maka sebaiknya dilakukan kegiatan lanjutan untuk lebih memperkenalkan hasil olahan kacang tanah yang lain. Selain itu mentega kacang yang dihasilkan oleh masyarakat Desa Cisitu dikembangkan menjadi produk olahan pangan komersil yang khas dari Desa Cisitu mengingat bahan bakunya sudah tersedia di Desa tersebut. Kualitas produk dan pengemasannya dikembangkan sehingga menjadi produk yang layak untuk dikomersilkan. Begitu juga halnya dengan Desa Situmekar, pupuk organik cair hasil pemanfaatan limbah cair industri tahu berpotensi untuk dikembangkan menjadi produk komersil. Jika kegiatan ini dilakukan secara rutin diharapkan dapat menumbuh kembangkan minat masyarakat terhadap dunia pertanian dan pengolahan hasil pertanian khususnya daerah 
marginal sehingga dapat meningkatkan kesejahteraan petani di masa yang akan datang dan terbentuknya industri rumahan (home industry) pengolahan hasil pertanian. Selain itu menumbuhkan kesadaran kepada masyarakat bahwa limbah tidak selalu merugikan, namun dapat diolah menjadi menjadi produk yang memiliki nilai ekonomis.

\section{SIMPULAN}

Kegiatan PPMD ini dapat meningkatkan pengetahuan dan keterampilan peserta di Desa Cisitu mengenai pemanfaatan kacang tanah sebagai bahan baku pembuatan mentega kacang serta meningkatkan pengetahuan dan keterampilan peserta di Desa Situmekar mengenai cara pengolahan limbah cair industri tahu menjadi pupuk organik cair. Kegiatan ini juga dapat memotivasi para peserta untuk mengembangkan usaha pengolahan mentega kacang dan pembuatan pupuk organik cair.

\section{DAFTAR PUSTAKA}

Anonim. 1992. Manajemen Limbah Industri Pangan. PAU Pangan \& Gizi. Yogyakarta: UGM.

Anonim. 2004. Laboratorium Pengujian Limbah dan Lingkungan dan Aneka Komoditi. Balai Riset dan Standarisasi Industri dan Perdagangan. Badan Penelitian dan Pengembangan Industri dan Perdagangan, Semarang. Departemen Perindustrian dan Perdagangan RI.

Betty Sri, L.J dan Winiati Pudji, R. 1993. Penangan Limbah Industri Pangan. Bogor: PAU Pangan \& Gizi IPB.

Buckle, K.A.1987. Ilmu Pangan. Jakarta: Universitas Indonesia Press.

Chariton, A.P dan Hadi. W. 2000. Studi Pertumbuhan Bed Lumpur Kaitannya dengan Produksi Biogas pada Pengolahan Limbah Pabrik Tahu dengan Reaktor Aliran Horizontal. Surabaya: Jurnal Purifikasi Vol.1 No.5 September 2000.

Damanhuri, E. 2001. Sludge Treatment. Badan Pelatihan Pengelolaan Limbah Cair Industri. Serpong: Pusdiklat BAPEDAL.

Droste, R. 1997. Theory and Practice of Water and Wastewater Treatment. Canada: John Wiley and Son.

Eckenfelder, W.W. 2000. Industrial Water Pollution Control 3rd Edition, International Edition. Singapore: Mc Graw-Hill Higher Education.

Hartati, M.E. 1998. Proses Pengolahan Air Limbah Industri Kecil Tahu Secara Aerobik-Anaerobik. Buletin Berita Lit Bang Industri 24: 45-55.

Hendarko, S. 2002. Mikrobiologi Dasar. Semarang: Jurusan Biologi Fakultas MIPA Universitas Diponegoro.

Jarwati, Sartantono dan Sukani. 1994. Peningkatan Energi dari Hasil Pengolahan Air Limbah Industri Tahu dan Tempe. Balai Penelitian dan Pengembangan Industri Departemen Prindustrian RI. Semarang
Mahida. 1984. Pencemaran Air dan Pemanfaatan Limbah Industri Pangan. Jakarta: CV Rajawali.

Mardisiwayo, P. 1993. Petunjuk Pencegahan dan Penanggulangan Pencemaran Limbah Padat dan Cair Industri. Jakarta: Departemen Perindustrian.

Marpaung, R dan Basuki, A. 2001. Pengolahan Lumpur Biologis dengan Proses Anaerob Digestion. Laporan Penelitian Mahasiswa Jurusan Teknik Kimia. Semarang: Universitas Diponegoro.

Partoatmojo, S. 1991. Karakteristik Limbah Cair Pabrik Tahu dan Pengolahannya dengan Ecenggondok (Eichormia Crasipes (Mart) Solums.

Pusat Penelitian Lingkungan Hidup Lembaga Penelitian Institut Pertanian Bogor.

Potter, C. Soeparwadi, M \& Gani A. 1994. Limbah Cair berbagai Industri di Indonesia. Sumber, Pengendalian dan Baku mutu. Enviromental Management Development in Indonesia (EMDI).

Reynolds, TD. 1982. Unit Operations and Processes in Environmental Engineering. Brooks/Cole Engineering Division. California: Monterey.

Rizal Syarif \& Haryadi Halid. 1993. Teknologi Penyimpanan Pangan. PAU Pangan \& Gizi IPB. Jakarta: Penerbit Arcan.

Setiadi, Tj. 2001. Pengolahan Limbah Cair Secara Sekunder (Biologi). Bahan Pelatihan Pengelolaan Limbah Cair Industri. Serpong: Pusdiklat BAPEDAL.

Sriharti, Tahiyah Salim dan Sukirno. 2004. Teknologi Penanganan Limbah Cair Tahu. Prosiding Seminar Nasional Rekayasa Kimia dan Proses Jurusan Teknik Kimia. Semarang: Universitas Diponegoro.

Yulianti, S dan Sarwoko Mangkoedihardjo. 2001. Penurunan COD Limbah Tempe dengan Anaerobic Horizontal Baffled Reactor serta Ekotoksisitasnya Terhadap Oryza sativa dan Phaseolus radiatus. Surabaya: Jurnal Purifikasi Vol 2 no.3, Mei 2001.

Yustikarini, RT dan Gogh Yoedihanto. 2000. Studi Kinerja Anaerobic Radial Mixing Reactor Terhadap Penurunan Kandungan COD dan SS Influen IPLT Sukilo, Surabaya: Jurnal Purufikasi Vol.1 no.3 Mei 2000.

Volk, W.A \& Wheeler,M.F, 1988. Mikrobiologi Dasar. Terjemahan dari Basic Microbiology. Fifth Edition, Editor Soemartono Adisoemarto. Penerbit Erlangga.

Winanto Rusli dan Agus Slamet, 2000.Studi Penurunan Kandungan Fosfat Dalam Limbah Tahu Dengan Sistem Biological Attacthed-Growth. Jurnal Purifikasi, Vol 1, No.3. Mei 2000 : 163-168 